Fikrah: Jurnal Ilmu Aqidah dan Studi Keagamaan

ISSN 2354-6147 EISSN 2476-9649

Tersedia online di: journal.stainkudus.ac.id/index.php/fikrah

DOI: 10.21043/fikrah.v6i1.2606

\title{
Konflik Internal Umat Islam Antara Warisan Sejarah dan Harapan Masa Depan
}

\author{
Egi Sukma Baihaki \\ Sekolah Tinggi Filsafat Islam Sadra Jakarta, Indonesia \\ egisukma_baihaki@yahoo.com
}

\begin{abstract}
Abstrak
Perbedaan kadang menjadi alasan untuk menindas orang atau kelompok lain yang berujung pada konflik antarumat beragama, bahkan dalam internal umat Islam. Keberadaan berbagai aliran, mazhab dan organisasi Islam terkadang membuat umat Islam terkotak-kotak dan saling mengklaim kebenaran. Hal ini yang juga diiringi kepentingan politik dengan kekuatan basis masa, semakin memperparah konflik internal. Dengan menggunakan pendekatan kualitatif berupa studi kepustakaan (library research), penulis menemukan bahwa konflik yang terjadi di internal umat Islam merupakan produk dan warisan sejarah baik itu disebabkan oleh kepentingan politik, maupun perbedaan pemahaman keagamaan. Selama ego, kepentingan politik dan fanatisme masih ada, perbedaan di antara pemeluk agama Islam sangat sulit untuk disatukan. Konflik baru dapat diselesaikan jika adanya mufakat untuk saling menghormati dan menjaga hubungan baik dengan mengedepankan semangat persatuan dan mengutamakan kepentingan agama. Penelitian ini dapat menjadi bahan masukan dalam merancang upaya penyelesaian konflik internal umat Islam.
\end{abstract}

Kata kunci: Kafir, konflik, sesat, toleransi, ukhuwah 


\begin{abstract}
The diversities becomes the reason for some of the people to oppress a person or group which different with them. This conflict often occurs in religious life. Even this conditions are occurring in the internal of Muslim too. Sometimes, the existence of various flow, madhab and Islamic organizations make Muslims fragmented and inevitably claim one another. The truth claim and political interests with the power of the mass aggravating the internal conflict. Chide each other, blaming and misleading people or groups become routines that we often encounter. By using a qualitative approach in the form of literature studies (Library Research) we will find that the internal conflicts of Muslims are both historical products and heritage caused by political interests, as well as differences in religious understanding. As long as the ego, political interests, and fanaticism still exist, the differences that exist between Muslims are very difficult to unite. Conflicts can be resolved if there is consensus to respect each other and maintain good relations by promoting a spirit of unity and prioritizing the interests of religion. This research is expected to be an input in designing efforts to resolve internal conflicts of Muslims.
\end{abstract}

Keywords: Conflict, kafir, misguided, tolerance, ukhuwwah

\title{
Pendahuluan
}

Sebagai makhluk sosial, manusia tidak bisa terhindar dari interaksi antar sesama, baik di bidang sosial, politik, budaya, agama dan lainnya. Perbedaan yang melekat pada diri setiap individu dalam berinteraksi dengan sesama pada kehidupan bermasyarakat seperti perbedaan fisik, intelektualitas, pengetahuan, adat istiadat, keyakinan dan lainnya yang sering mengakibatkan konflik dan dianggap sebagai sesuatu kondisi yang lumrah (biasa). Konflik hanya akan hilang dan tidak terjadi jika masyarakat tidak pernah ada (Aisyah BM, 2014, hal. 193). Konflik Timur Tengah sering dianggap sebagai bentuk dari perpecahan umat Islam. Tidak bersatunya bangsa Arab mengakibatkan peperangan terus terjadi, dan telah mengorbankan banyak pihak terutama umat Islam. Satu dengan lainnya saling menjatuhkan, menghina, merusak hingga membunuh. Realitasnya persaingan politik dan kekuasaan yang terjadi di Timur Tengah hanyalah bagian kecil dari warisan peradaban masa lalu. Jika kita telisik lebih dalam, konflik yang terjadi di internal umat Islam memiliki latar belakang sejarah dan dimensi tersendiri yang berbeda-beda.

Menurut Tuakia (2015, hal. 10), konflik internal umat Islam mulai muncul sejak adanya perbedaan pemahaman dan praktik keagamaan dalam menyikapi ajaran-ajaran 
Islam yang bersifat furu', bukan pada ajaran Islam yang bersifat fundamental. Kondisi yang lebih memperihatinkan adalah ketika umat Islam menggaungkan toleransi antar umat beragama dalam kehidupan bermasyarakat, namun realitanya di dalam tubuh umat Islam sendiri, nilai toleransi belum terbangun dengan baik. Masih ada umat Islam yang saling menyalahkan, membid'ahkan, menyesatkan, mengkafirkan sesama umat Islam yang hanya disebabkan perbedaan pemahaman keagamaan dan pendapat. Karena perbedaan pendapat hingga membuat sebagian orang menjadi fanatik dan taklid buta. Hal tersebut menyebabkan tidak sedikit orang yang melarang dan membatasi sesama umat Islam dalam beribadah, bahkan menghalalkan darah dan kehormatan sesama umat Islam sendiri. Penyebab konflik yang sering terjadi bermula dari perbedaan mazhab fiqih, maupun teologi yang dianut, sehingga memunculkan konflik Sunni, Syi'ah dan Wahabi, sebagaimana yang sering terjadi di Indonesia. Kondisi konflik internal umat Islam semakin diperparah dengan munculnya kelompok kaum ekstrimisradikal seperti ISIS yang menebarkan teror kepada negara Eropa dan negara-negara yang penduduknya didominasi umat Islam.

Konflik internal umat Islam merupakan ancaman serius bagi terwujudnya persatuan dan keutuhan umat Islam. Konflik ini harus segera diatasi dan tidak berkepanjangan sebagaimana dialami oleh umat Islam saat ini yang harus merasakan akibat konflik internal yang sudah diwariskan oleh para pendahulu. Oleh karena itu pentingnya membangun kesadaran bersama dalam membangun kerukunan yang dimulai dari para tokoh agama yang menjadi panutan para umat, dengan menyampaikan pesan-pesan agama secara bijaksana, tanpa memunculkan unsur kebencian dan menjelek-jelekkan kelompok lain (Farihah, 2014, hal. 314).

\section{Metode}

Untuk merangkai menjadi sebuah pembahasan yang dapat memberikan solusi bagi konflik yang terjadi di internal umat Islam. Peneliti menggunakan metode kualitatif yaitu studi pustaka (library research) dengan menelusuri literatur-literatur yang berkaitan pembahasan di artikel ini. Dengan metode ini, berdasarkan literatur yang digunakan dapat diketahui bahwa konflik yang terjadi di internal umat Islam merupakan konflik berkepanjangan dan dampak dari perdebatan umat Islam pada masa 
klasik. Penelitian ini akan mengungkap apa penyebab perpecahan umat Islam, dampak apa saja yang kemudian terjadi setelah terjadinya perpecahan umat Islam dan solusi apa yang dapat diberikan untuk mengatasi konflik internal umat Islam.

\section{Sejarah Perpecahan dan Politik Kekuasaan}

Wafatnya Nabi menjadi pintu awal terjadinya perpecahan di antara umat Islam. Masalah yang pertama kali muncul dalam sejarah ketika itu adalah siapa yang berhak atas kepemimpinan umat Islam pasca wafatnya Rasulullah (Jamrah, 2015, hal. 4-5). Hal ini yang membuat umat Islam terpusatkan perhatiannya pada persoalan politik yaitu permaslahan siapa pengganti posisi Nabi Muhammad sebagai pemimpin negara, karena Nabi memiliki dua kedudukan sekaligus yaitu kedudukan pemimpin agama dan pemimpin negara. Posisi sebagai Nabi memang tidak dapat tergantikan, tapi posisi sebagai pemimpin negara meniscayakan keharusan adanya pengganti demi menjaga keutuhan dan politik umat Islam.

Menurut Jamrah (2015, hal. 5-6) dalam menyikapi persoalan khilafah ini, umat Islam terpecah menjadi tiga kelompok yaitu kelompok Muhajirin, Anshar dan kelompok Bani Hasyim. Kaum Muhajirin, merupakan yang pertama merasa berhak untuk menduduki posisi politik tersebut. Sedangkan kaum Anshar merasa pantas atas posisi khilafah karena mereka merasa memiliki banyak sumbangsih terhadap Islam. Sementara itu, kelompok Bani Hasyim, sebagai keluarga dekat Rasulullah, juga lebih merasa berhak dan pantas menduduki jabatan politik sebagai khilafah dengan mengusung Ali yang merupakan sepupu sekaligus menantu Nabi.

Pada saat itu kaum Anshar berkumpul untuk membicarakan siapakah dari kalangan Anshar yang layak menggantikan kedudukan Nabi sebagai pemimpin umat Islam. Akan tetapi usaha mereka diketahui oleh beberapa sahabat termasuk Abu Bakar dan Umar sehingga dari pertemuan itu justru menghasilkan Abu Bakar sebagai pengganti Nabi sebagai pemimpin umat Islam. Menurut Andiko (2013, hal. 40) karena persoalan inilah pemakaman jenazah Nabi baru dapat terlaksana setelah pengganti kepemimpinan umat Islam terpilih. Kejadian ini termasuk dalam persoalan politik dan menjadi awal dari munculnya persoalan khilafah yang kemudian terus berkembang dan melahirkan berbagai macam pandangan di kalangan pemikir politik di dunia Islam. 
Ternyata masalah politik di zaman klasik tidak pernah usai. Pertikaian kembali terjadi di saat Usman menjadi khalifah (Azra, 1999, hal. 90) dan pada akhirnya terjadi konflik di antara umat Islam. Muncul pihak yang menentang pada pemerintahan Usman dianggap telah melakukan nepotisme karena anggota keluarganya kerap kali menduduki jabatan politik yang penting dan strategis. Usman pada akhirnya dibunuh oleh kelompok yang memprotes dan melakukan pemberontakan terhadap kepemimpinannya. Terbunuhnya Usman dan pengangkatan Ali sebagai khalifah sesudahnya, tidak dapat memadamkan gejolak perpolitikan yang tengah memanas ketika itu. Perang Jamal adalah peristiwa perang antara pihak Ali melawan Aisyah yang menuntut agar para pembunuh Usman diadili. Perang ini menewaskan banyak sahabat Nabi dari kedua belah pihak termasuk tewasnya Thalhah bin Ubaidilah dan Zubair bin Awwam. Madjid (1993, hal. 14) mengungkap bahwa peristiwa pembunuhan Usman dan Perang Jamal yaitu perang antara Ali dan Aisyah merupakan bagian dari empat fitnah yang terjadi dalam sejarah umat Islam.

Belum lagi pemberontakan Muawiyah seorang gubernur yang diangkat oleh Usman dan masih memiliki hubungan kerabat dengannya, menyatukan kekuatan untuk melawan Ali. Perang Siffin pun meletus dan pada akhirnya pihak Ali mau menerima tahkim dengan terpaksa dan terpedaya oleh siasat politik Amr bin Ash. Pasca perang Siffin umat Islam terkotak-kotak menjadi pengikut Ali (Syi'ah), pembelot (Khawarij) dan pendukung Muawiyah. Bahkan gerakan Khawarij yang membelok dari pasukan Ali berencana membunuh para pemuka yang mengikuti proses tahkim, akan tetapi yang berhasil dibunuh hanyalah Ali (Nasution, 1986, hal. 8). Khawarij memandang bahwa Ali, Muawiyah, Amr bin Ash, Abu Musa al-Asy'ari dan orang-orang yang menerima tahkim adalah sebagai orang kafir. Mereka dianggap kafir dalam arti keluar dari Islam atau murtad dan mesti dibunuh karena telah bertentangan dengan al-Quran, sebagaimana dalam QS. al-Maidah 44.

Berawal dari peristiwa perang Siffin dan lahirnya kelompok Khawarij dengan pandangan tersebut menjadi awal dari dimulainya perdebatan teologis di kalangan umat Islam khususnya bagi kelompok teologi yan lain. Rusli $(2015$, hal. 2) menjelaskan bahwa persoalan "Murtakib al-Kabair (pelaku dosa besar)" memiliki pengaruh yang dominan dalam lahirnya teologi Islam. Pembahasan yang dibahas adalah jika seorang mukmin 
melakukan dosa besar apakah masih dihukumi sebagai muslim atau sudah menjadi kafir? Dalam menyikapi pembahasan ini lahir tiga aliran: Pertama, Khawarij yang menyatakan bahwa pelaku dosa besar itu kafir dan keluar dari Islam, serta wajib dibunuh. Kedua, Murjiah yang menganggap bahwa orang tersebut tetap mukmin dan tidak kafir. Ketiga, Muktazilah yang menganggap bahwa posisi orang tersebut berada di tengah-tengah antara mukmin dan kafir. Hal ini berbeda dengan dua paham sebelumnya, sehingga istilah Muktazilah bagi kelompok ini pun menguat.

Pada periode selanjutnya, muncul aliran teologi lainnya seperti Asy'ariyah, Maturidyah dan Syiah. Syi'ah memang memainkan peran paling awal dalam sejarah Islam, tapi dalam segi perkembangan pemikiran teologi baru muncul belakangan. Dalam satu aliran berkembangan dan melahirkan beberapa sekte. Pembahasan yang diperbincangkan tidak hanya soal status pelaku dosa besar, tapi meluas ke masalah lain seperti sifat Tuhan, kedudukan al-Quran, kedudukan akal, akal dan wahyu, perbuatan manusia, kekuasaan dan keadilan Tuhan, anthropomorphisme, kasab, melihat Tuhan, perbuatan Tuhan dan lain-lain (Rusli, 2015, hal. 3).

Sejarah menceritakan, bahwa Syi'ah awalnya bukan bagian dari kelompok yang memiliki pandangan keagamaan yang khas. Syiah muncul akibat faktor perdebatan politik tentang siapa yang berhak menjadi khalifah setelah Nabi wafat. Syi'ah meyakini Ali bin Abi Thalib dan keturunannya lebih berhak menjadi khalifah berdasarkan wasiat Nabi. Sementara Sunni beranggapan bahwa persoalan politik tersebut sebaiknya diselesaikan dengan mekanisme pemilihan. Syi'ah hanya mengakui kepemimpinan Ali, sedangkan Sunni mengakui kepemimpinan keempat sahabat secara keseluruhan. Para pendukung Ali berubah menjadi kelompok Syi'ah setelah kepemimpinan Ali direbut oleh Muawiyah (Masduqi, 2011, hal. 208). Bahkan menurut Mulyono (2012, hal. 249) bahwa di kalangan Syi'ah terdapat anggapan bahwa Ali ibn Abi Thalib tidak berbaiat kepada Abu Bakr sampai Fatimah meninggal. Secara umum Syiah meyakini bahwa persoalan imamah merupakan hal yang wajib dan Ali ibn Abi Thalib merupakan figur yang pantas menduduki posisi tersebut. Persoalan imamah yang merupakan hak dari ahl al-bayt yang terlepas ke tangan Abu Bakar, Umar bin Khatab dan Usman bin Affan. 
Sementara itu, telah lahir pula dua aliran kalam yang mempunyai perbedaan pandangan dan saling bertentangan yaitu aliran Jabariyah dan Qadariyah. Persoalan yang dibahas oleh kedua aliran ini adalah tentang "perbuatan manusia" (afal al-Ibad). Masalah yang dibincangkan sekitar perbuatan manusia yaitu "apakah perbuatan manusia itu merupakan perbuatan Tuhan atau perbuatan manusia itu sendiri" (Nurdin \& Abbas, 2012, hal. 8-9).

Keberadaan aliran teologi bukan hanya masuk ke dalam kehidupan masyarakat tapi juga masuk ke dalam lingkungan pemerintahan. Pertumbuhan aliran teologi dan mazhab sangat bergantung kepada bagaimana sikap seorang penguasa saat itu. Jika mendukung, maka mereka akan tumbuh subur, tapi jika tidak maka akan diberangus. Tidaklah aneh jika saat kerajaan-kerajaan Islam mulai berdiri, maka menetapkan satu aliran atau mazhab sebagai aliran atau mazhab resmi kerajaan. Konsekuensinya mazhab atau aliran lain dilarang berkembang atau diawasi bahkan dibatasi kegiatannya. Dalam sejarahnya banyak sekali mazhab yang ada di Islam, tapi hanya beberapa saja yang sampai kepada kita. Hal itu disebabkan beberapa mazhab tidak mendapat respon dari penguasa di masanya dan kurang diminati oleh umat saat itu. Dengan posisi yang strategis karena didukung oleh penguasa, membuat aliran-aliran tersebut menyalahgunakan kewenangan dan kondisi yang ada, contohnya adalah kasus yang menimpa para ulama ketika Muktazilah dijadikan mazhab resmi Abbasiyah, salah satunya Ahmad bin Hanbal yang terpaksa harus mendekam di penjara karena melawan arus kala itu.

Menurut Hatta (2013, hal. 96) dengan mendapatkan pengakuan resmi dari pemerintah, maka secara otomatis aliran ini mendapat dukungan dan perlindungan dari penguasa ketika itu. Selanjutnya aliran ini dengan bebas dan berani menyebarkan pahamnya kepada publik. Penyebaran tersebut dilakukan dengan berbagai cara mulai dari cara yang lemah lembut sampai dengan menggunakan pemaksaan dan kekerasan. Puncak kekerasan dan pemaksaan yang terjadi adalah berkaitan dengan pembahasan "al-Quran makhluk". Pembahasan tersebut sampai melahirkan peristiwa al-Mihnah yaitu pemeriksaan terhadap para ulama ahli Hadis dan ahli fikih oleh Khalifah alMakmun pada masa Dinasti Abbasiyah. 
Masalah kedua yang diperdebatkan oleh umat Islam berkaitan dengan keagamaan dan hukum adalah pemegang otoritas pasca Nabi wafat. Siapa yang memiliki otoritas pasca Nabi wafat? Karena sebelumnya, Nabilah yang memiliki otoritas dalam menjelaskan al-Quran dan hukum-hukum melalui hadisnya, menyelesaikan permasalahan dan juga konflik menjadi pemimpin atau pembuat strategi dalam peperangan. Otoritas keagamaan ini sering dikaitkan dengan pemaknaan salaf oleh umat Islam. Menurut Siroj (2012, hal. 57) kata salaf secara bahasa satu makna dengan kata qabla, yang berarti "sebelum" atau "yang lampau". Kata ini sering dilawankan dengan kata khalaf, yang bermakna "yang belakangan". Dalam perkembangannya, makna istilah salaf menyempit untuk menyebut suatu sejarah (babakan historis) tertentu dalam sejarah Islam yang berwenang memberi legitimasi terhadap kurun dan periode sesudahnya.

Otoritas dalam Sunni diberikan kepada para sahabat hingga kemudian dalam pengambilan hadis sebagai sumber hukum muncul istilah adanya atsar atau khabar dalam dunia hadis. Bagi Syi'ah, otoritas ini hanya diberikan kepada Ali dan keturunannya, oleh karena itu prinsip kehadiran Imam menjadi penting dalam rangka menjelaskan hal-hal yang berkaitan dengan persoalan-persoalan yang dialami umat. Perpecahan umat Islam juga berdampak pada perbedaan dalam menentukan siapa yang memiliki otoritas keagamaan pasca Nabi wafat (Siroj, 2012, hal. 58). Kondisi tersebut berdampak terhadap pemaknaan salaf. Subyektivitas dan fanatisme kelompok dan aliran pasti akan mempengaruhi sikap mereka terhadap persoalan salaf. Jumhur Ulama, Sunni, tabi' tabi'in dan pengikutnya menganggap bahwa khalifah yang empat semuanya memiliki otoritas salaf. Sedangkan Khawarij berpadangan yang memiliki otoritas hanya Abu Bakar dan Umar, namun bagi Syi' ah hanya mengakui otoritas Ali.

\section{Klaim Kebenaran}

Masing-masing kelompok tentunya memiliki keyakinan yang dinamakan agama dan sumber kebenarannya didasarkan pada Tuhan. Namun dalam kajian sosiologis, kebenaran tersebut akhirnya menjadi klaim masing-masing kelompok dan mudah menyalahkan kelompok lain salah, yang akhirnya klaim kebenaran berubah menjadi sebuah simbol keyakinan masing-masing kelompok yang dipahami seara subyektif dan 
personal yang menimbulkan perbedaan yang tidak dapat terlepas dari latar belakang dari orang yang meyakininya. Mereka mengklaim telah memahami, memiliki, bahkan menjalankan secara murni dan konsekuen nilai-nilai suci dari langit (Kahmad, 2002, hal. 170). Keyakinan tersebut menjadi legitimasi dari semua perilaku pemaksaan konsep-konsep yang ada pada diri seseorang maupun kelompoknya kepada yang berbeda keyakinan dan pemahaman kepada mereka.

Menurut Yunus (2014, hal. 220) kecenderungan umat beragama berupaya membenarkan ajaran agamanya masing-masing, meskipun ada di antara mereka yang tidak paham terhadap nilai-nilai luhur yang terkandung dalam agama yang dia bela dan yakini. Namun semangat yang menggelora kadang kala telah merendahkan orang lain yang tidak sepaham dengannya meskipun mereka satu agama. Harus diakui keyakinan tentang yang benar itu didasarkan kepada Tuhan sebagai satu-satunya sumber kebenaran. Pluralitas manusia membuat wajah kebenaran itu terlihat berbeda ketika akan dimaknakan. Sebab perbedaan ini tidak dapat dilepaskan begitu saja dari berbagai referensi dan latar belakang orang yang meyakininya. Mereka mengklaim telah memahami, memiliki, bahkan menjalankan secara murni terhadap nilai-nilai suci tersebut. Peristiwa historis perselisihan di ranah politik-kekuasaan umat Islam bertanggung jawab terhadap kesadaran sektarian umat Islam, dan perpecahan umat Islam kebeberapa kelompok. Polemik kekuasaan yang berkembang cenderung menggunakan wacana keagamaan sebagai alat pembenaran. Peristiwa tahkim telah memunculkan sekte-sekte dalam Islam, yaitu sekte Khawarij, Syi'ah dan Murjiah. Tidak sedikit sejarawan mengaitkan kemunculan kelompok-kelompok tersebut dengan hadis predikatif yang menyatakan bahwa umat Islam akan terpecah menjadi 73 golongan (Purnama, 2016, hal. 215-216).

Munculnya perasaan fanatik terhadap mazhab yang dianut, membuat umat Islam menganggap kelompok mereka yang paling benar dan menyalahkan kelompok lain. Klaim kebenaran ini dianut oleh para pengikut aliran teologi Islam termasuk Sunni dan Syi'ah. Bahkan klaim kebenaran ini juga menjadi perpecahan di antara sekte-sekte lain seperti saling tuduh antara ahli fiqih dengan tasawuf atau ahli fiqih dengan sesama ahli fiqih. Hadis perpecahan umat Islam menjadi 73 golongan inilah yang sering dijadikan pedoman para golongan yang menganggap dirinya paling benar dibanding 
golongan lain dan dengan hadis inilah masing-masing ulama dari berbagai mazhab kemudian menafsirkan kelompok mana saja yang termasuk 72 golongan itu.

Para penulis sejarah aliran dan sekte banyak yang mengacu kepada hadis tersebut dalam mengklasifikasi golongan dan mazhab dalam Islam. Hanya saja mereka berbeda di dalam menentukannya. Misalnya, asy-Syahrastani dalam kitabnya al-Milal wan-Nihal dan Ibn Jauzi dalam kitabnya Talbisu Iblis menyebutkan bahwa secara garis besar golongan dalam Islam terbagi menjadi enam bagian, dan yang enam tadi terpecah hingga mencapapai 73 golongan. Namun dalam kenyataannya, kadang mereka menemukan lebih dari 73 golongan. Penjumlahan hasil tersebut jika dilihat dalam sejarah di masa mereka sudah seperti itu, lantas bagaimana dengan saat ini di saat umat Islam terpecah menjadi berbagai kelompok dan mazhab yang lebih banyak lagi (AlQadri, 2012, hal. 66). Para muhadisin juga masih mempermasalahkan keshahihan hadis tersebut. Mungkin yang paling disahihkan oleh para pakar hadis adalah hadis riwayat at-Tirmidzi, yang disahihkan juga oleh al-Hakim. Al-Hakim menyatakan bahwa hadis ini sahih menurut syaratnya Imam Muslim karena di dalam sanadnya ada Muhammad bin Amr yang merupakan periwayat hadis-hadis Imam Muslim. Tetapi menurut adzDzahabi, Imam Muslim tidak menjadikannya sebagai hujjah dalam riwayatnya, posisi Muhammad bin Amr hanya sebagai penguat. Hadis yang disahihkan oleh al-Hakim tidak ada kata-kata yang berbunyi "semuanya di neraka kecuali satu" (Al-Qadri, 2012, hal. 67).

Sementara itu menurut Rakhmat (2004, hal. 28) hadis tentang 73 golongan menurut kritik sanad, bukan hadis yang shahih. Dalam rangkaian perawi hadis itu, ada nama-nama yang dha'if, seperti Muhammad bin Amr, Abdurrahman bin Ziyad bin An'am, Katsir bin Abdullah, 'Ubad bin Yusuf, Rasyid bin Sa'ad, al-Walid bin Muslim dan yang lainnya (periksa kitab Tahdzib al-Tahdzib, Lisan al-Mizan dan Mizan alI'tidal). Menarik untuk dicatat bahwa menurut beberapa peneliti hadis seperti Muhammad al-Ghazali dan Muhammad al-Basyari dalam kitab Ahsan al-Taqasim, hadis yang lebih shahih adalah yang mengatakan "Umatku akan pecah menjadi tujuh puluh tiga golongan. Semua masuk surga kecuali satu." Bila kita menerima keterangan ini, maka yang dimaksud dengan perpecahan adalah perbedaan pendapat. Berapapun banyaknya perbedaan pendapat yang alamiah, maka pendapat itu akan membawa orang 
masuk ke surga, kecuali pendapat yang jelas-jelas membenarkan kemaksiatan kepada Allah dan Rasul akan membawa orang ini ke neraka.

Terlepas dari banyaknya periwayatan dan status hadis perpecahan ini, pada akhirnya umat Islam pun saling mengklaim sebagai kelompok yang satu sebagaimana yang dimaksud oleh hadis tersebut, dan menjustifikasi kelompok lain ke dalam golongan yang tidak akan selamat (Waskito, 2012, hal. 72). Hadis seputar iftiraqul ummah kerap kali digunakan sebagai dalil oleh sebagian orang untuk melegitimasi kebenaran kelompoknya dan menihilkan yang lain. Kondisi ini adalah sebuah realita dalam kehidupan umat Islam. Terdapat kelompok yang mendakwahkan bahwa umat Islam terpecah menjadi 73 golongan, satu golongan akan masuk surga dan sisanya masuk neraka. Satu golongan yang selamat itu diklaim adalah kelompok mereka, sedangkan kelompok lain akan berada di neraka. Ketika pendakwah mendakwahkan hadis-hadis tersebut pasti tidak akan mengklaim kelompok mereka sebagai bagian dari yang 72 golongan itu, pasti akan mengklaim sebagai firqah an-najiyah (kelompok yang selamat) baik itu secara sadar ataupun tidak. Meskipun pada dasarnya ada perbedaan antara kelompok teologi dan kelompok hadis dalam memahami perpecahan umat Islam atau kemunculan firqah dalam Islam. Bagi kelompok teologis, perpecahan lebih disebabkan oleh kekosongan otoritas setelah wafatnya Nabi, tetapi bagi kelompok hadis perpecahan yang terjadi di tubuh Islam disebabkan berbagai faktor, termasuk lemahnya umat Islam.

Fanatisme dan klaim kebenaran dapat membutakan mata manusia termasuk mata hati, tidak dapat lagi mengontrol emosi dan pikiran. Kurangnya pengetahuan dan informasi tanpa terlebih dahulu mendalami sesuatu dan melakukan tabayyun dapat menjerumuskan manusia pada kesombongan dan melakukan tindakan di luar batas. Klaim kebenaran dengan menganggap bahwa hanya kelompok atau pengikut dari ulama, mazhab dan aliran tertentu yang benar dan yang lain salah, merupakan sebuah kekeliruan. Haidar Bagir mengungkapkan bahwa dalam sejarah pertumbuhan mazhab telah terjadi perkembangan yang menyebabkan dalam satu mazhab memiliki beragam pandangan. Pandangan seorang guru, murid dan penerus suatu mazhab kadang kala saling berbebeda. Apalagi para imam mazhab kerap kali merelatifkan pandangan mereka (Bagir, 2017, hal. 122). 


\section{Pengkafiran dan Penyesatan}

Berkembangnya berbagai aliran teologi dan perubahan zaman. membuat orang mudah sekali mengklaim individu atau kelompok yang dianggap tidak sesuai atau bertentangan dengan "konsep" yang dipahami oleh mereka sebagai musuh atau bahkan memberikan label "sesat" dan "kafir" kepada. Realita pada kehidupan umat Islam label seperti ini justru dilontarkan terhadap sesama umat Islam. Dengan yang lintas agama sudah dapat meerima dan toleransi dengan baik, namun dengan sesama Islam yang belum dapat membangun harmoni dengan tulus. Sedangkan menurut Biyanto (2015, hal. 167) jika kita membaca kembali sejarah Islam masa klasik, maka akan tergambar dalam pikiran betapa umat Islam sangat sulit dipersatukan. Lebih menyedihkan lagi karena kondisi tersebut terjadi pada masa yang masih sangat dini yaitu pasca wafatnya Nabi. Umat Islam saat itu telah terpecah dalam banyak kelompok politik. Bermula dari persoalan politik, terutama dalam penentuan pengganti Rasulullah, kemudian beberapa aliran (firqah) keagamaan bermunculan.

Kita juga mengenal beberapa aliran dalam bidang kalam (teologi Islam) seperti Qadarîyah, Jabariyah, Murjiah, Khawarij, Mu'tazilah dan Asy'ariyah. Itu belum termasuk aliran-aliran politik yang mewakili dan dikaitkan dengan kelompok Sunnî dan Syi'ah. Ironisnya, dalam menyikapi perbedaan tersebut terjadi gejala saling mengafirkan, bahkan terjadi saling membunuh antar satu sama lain. Siroj (2012, hal. 59) juga menjelaskan bahwa perpecahan umat semakin kusut, ibarat benang yang ruwet yang justru semakin sulit dipertemukan dan diluruskan. Setiap kelompok mengklaim dirinyalah yang paling benar. Bahkan ada yang berpandangan ekstrem dengan mencap kelompok di luar dirinya sebagai golongan sesat (dlalalah). Oleh karena itu, sektarianisme tersebut segera dipangkas dengan merujuk kepada sabda Nabi Saw., "Perbedaan (pendapat) di kalangan umatku merupakan suatu rahmat."

Khawarij dianggap sebagai peletak dasar kelompok yang mudah menjustifikasi individu atau orang lain yang berbeda dengan dirinya sebagai orang kafir, kini fenomena tersebut masih terus berlanjut dan sering dijumpai dalam kehidupan umat Islam. Perkembangan justifikasi "tafkiri" belakangan ini dilakukan tanpa mengetahui permasalahan yang sebenarnya dan tidak melakukan klarifikasi. Dengan demikian tindakan mudah mengklaim orang lain dengan sebutan "kafir", karena dapat memicu 
konflik di internal umat Islam. Selain itu tindakan tersebut dapat menimbulkan keresahan dan memprovokasi masyarakat yang sudah memeiliki fanatisme terhadap golongan tersebut. Terdapat tiga label yang selalu menjadi "umpatan" yang dilontarkan di antara sesama umat Islam yaitu kafir, sesat dan bid'ah.

Realitas masyarakat Islam saat ini menjadi keprihatinan kita bersama sebagai umat Islam, sebagaimana disampaikan Shihab (2017, hal. 3) yang merasa prihatin terhadap kondisi belakangan ini pada tataran umat Islam, perbedaan lebih sering menjadi alasan untuk tercerai-berai, bergesekan, bahkan saling hantam dan ingin mempertahankan kelompok masing-masing tanpa memikirkan kelompok lain. Perbedaan terlihat sebagai sesuatu yang tidak wajar dan menyebabkan kelompok lain terusik atas perbedaan yang terjadi. Perbedaan dilihat melalui sudut pandang sentimen dan pemicunya bisa beragam, mulai dari sikap sektarian dan perpautan terhadap suatu mazhab tertentu yang berlebihan, pengetahuan yang sempit, sikap irrasional dan condong emosional, cinta dunia, sampai sikap eksklusif yang terus dipelihara. Dampaknya, sikap-sikap negatif seperti ini menjurus terhadap ketidak jelasan sesuatu secara menyeluruh atau tidak netral atas pendapat atau pemahaman di luar pendapat atau pemahamannya. Hal ini diperkeruh dengan sikap gemar membuat pernyataanpernyataan hasutan mengenai kelebihan diri dan kelompok sendiri sambil melemahkan dan mencibir kelompok yang lain. Akhirnya titik tengkar lebih mereka sukai dari pada titik temu.

Tafkiri dalam Latiff (2003, hal. 30) menganggap orang yang berbeda dengan pemahaman yang dimiliki oleh sebagian kelompok sebagai orang atau kelompok yang keluar atau bukan bagian dari Islam merupakan isu sensitif. Isu takfir tersebut sangat sensitif kerana menyentuh persoalan aqidah yang berdampak buruk terhadap penghalalan darah seseorang, termasuk kepada orang Muslim. Isu takfir juga menimbulkan implikasi terputusnya hubungan nasab antara suami-isteri dengan anak, hilangnya hak warisan, hak kewarganegaraan di negara Islam dan sebagainya. Oleh itu, isu tersebut wajib ditangani dengan hati-hati dan teliti oleh semua pihak yang terlibat.

Menurut Rumadi (2012, hal. 29) persoalan otoritas, khususnya otoritas keagamaan, menjadi ajang kompetisi berbagai kelompok keagamaan. Dengan memegang otoritas, tidak jarang tindakan-tindakan otoriter dipertontonkan dengan 
menghakimi kelompok lain yang dianggap melenceng dari rel keagamaan yang mainstream. Tidak hanya soal penghakiman "aliran sesat", otoritas juga sering digunakan untuk mengatur pemeluk agama lain. Mengatur yang dimaksud adalah untuk mengendalikan perilaku pemeluk agama lain yang dikhawatirkan dapat mengancam agama pemilik otoritas tersebut. Dengan memiliki otoritas, Tuhan seolah bersemayam dalam diri orang tersebut yang membuat ucapan dan tindakannya dipandang mewakili ucapan dan tindakan Tuhan. Akibatnya, melawan ucapan dan tindakan pemegang otoritas tersebut diklaim sama dengan melawan Tuhan. Pada titik ekstrem ini, otoritas agama akan mengancam keragaman dalam kehidupan beragama, baik itu pada keragaman pemahaman agama maupun keragaman ekspresi keagamaan.

Perbedaan pandangan, bertentangan dengan pemuka agama yang dihormati oleh suatu kelompok, persoalan figh dan lain-lain seperti jumlah rakaat shalat tarawih, praktik berwudu, ucapan sayyidina atau tidak dalam bershalawat, qunut atau tidak pada shalat subuh, tidak harus membuat sesama umat Islam saling mengkafirkan dan membid'ahkan. Jika kita melakukan sesuatu karena dalil-dalil yang kita yakini, orang lain pun melakukannya dengan dalil-dalil tertentu. Sudah seharunya umat Islam menjaga lisan dan prasangka kepada sesama. Tidak mudah mengkafirkan, menyesatkan dan membid'ahkan orang lain. Islam sendiri melalui hadis Nabi mengecam dan melarang perbuatan mudah mengklaim orang lain kafir, karena dengan prasangka buruk, ego dan emosi dapat menyebabkan kita melakukan tindakan di luar batas hingga merusak bahkan membunuh orang lain yang kita anggap sesat ataupun kafir (Abdillah, 2014, hal. 23). Perbedaan pendapat dalam hukum Islam (ikhtilafatu al-fiqhiyah) bagaikan buah-buah yang berasal dari satu pohon yang sama, yaitu pohon al-Quran dan Sunnah, buah-buah itu bukam berasal dari pohon yang berbeda. Akar dan batang pohon itu adalah al-Quran dan Sunnah, cabang-cabangnya adalah dalil-dalil naqli dan aqli, sedangkan buahnya adalah hukum Islam (fiqh) meskipun berbeda-beda atau banyak jumlahnya.

Menurut Alfandi (2013, hal. 124) antara konflik dan praduga mempunyai hubungan yang saling berkaitan. Praduga masih memuat sikap, pikiran, keyakinan, kepercayaan yang negatif terhadap kelompok tertentu dan melalui praduga inilah akan memunculkan tindakan diskriminasi. Jika praduga masih berada di pikiran seseorang, 
tetapi diskriminasi sudah dapat mengarah ke tindakan terstruktur, maka diskriminasi akan memunculkan tindakan yang berusaha menyingkirkan status dan peran orang lain dari hubungan, pergaulan, serta komunikasi antar sesama. Melalui tindakan diskriminasi inilah lama-kelamaan tentu akan memunculkan konflik dikalangan umat Islam sendiri.

\section{Mewujudkan Toleransi dan Persatuan Umat Islam}

Manusia harusnya meyadari bahwa keragaman dan perbedaan dalam berpendapat adalah sebuah keniscayaan yang harus diterima dan dihadapi. Meskipun demikian seringkali ditemukan sikap yang tidak sepakat dengan keragaman, sehingga hal ini yang sering menjadi penyebab terjadinya konflik antar individu maupun kelompok. Jika dilihat dari sumber ajaran Islam, bahwa Allah telah menciptakan manusia dalam keragaman dan kesatuan, sebagaimana QS. al-Hujurat 13 yang menjelaskan secara lugas tentang keragaman yang tujuannya untuk saling mengenal (lita'arafu) bukan saling mencari berbedaan dan berseteru, oleh karenanya memungkinkan manusia mewujudkan sikap toleransi dalam menyikapi berbagai pemahaman yang diyakini masing-masing individu maupun kelompok. Kasih sayang Allah mendorong manusia mempertahankan ajaran Islam yang selalu menekankan sisi kemanusiaan. Islam juga menegaskan universalisasi prinsip-prinsip moral yang memperkuat hubungan antar anggota masyarakat, mempersatukan perasaan yang merupakan dasar kebaikan dan mempersatukan kaidah-kaidah yang memaksa dan sangat penting bagi kehidupan kolektif (Harahap, 2011, hal. 106).

Al-Quran secara tegas menyatakan bahwa umat Islam adalah umat yang satu. Dalam ayat lain, al-Quran melarang umat Islam untuk berpecah belah. Jika selama ini kita selalu menggaungkan toleransi dengan agama lain, dan mengharapkan kedamaian antar umat beragama, pada kenyataannya umat Islam melupakan toleransi dalam internal Islam sendiri. Menurut Syak'ah (2008, hal. 669) banyak mazhab dan perselisihan beberapa kelompok membawa dampak yang buruk dan berbahaya bagi Islam dan kaum muslimin. Islam ditandai dengan toleransi dan selalu menyeru pada keselamatan bagi seluruh umat. Sungguh darah para generasinya sudah diwarnai dengan darah-darah dari sebagian yang lain akibat perselisihan mazhab dan sempitnya 
kesadaran pada mereka yang fanatik terhadap mazhab masing-masing. Permaslahan tersebut sebagian besar berakhir dengan peperangan berdarah yang meninggalkan kegagalan pada diri kaum muslimin, dari generasi beragam kelompok

Perbedaan kadang disalah artikan dan dijadikan pemicu konflik. Perbedaan merupakan hal alamiah yang pasti ada dan perlu disikapi dengan bijak (Ahmad, 2015, hal. 223). Perbedaan juga merupakan bagian dari sunnatullah. Akan tetapi, perbedaan jika tidak dikelola dengan baik, maka akan mudah menyulut konflik. Sebagaimana yang disampaikan Shihab (2017, hal. 16) selama perbedaan dipahami dan disikapi secara bijaksana dan positif, maka hal tersebut akan menjadikan kehidupan ini lebih baik dan menarik untuk dilalui dan dirasakan. Perbedaan itu membuat umat Islam dengan masing-masing pendapatnya, akan dapat berdiskusi secara sehat dan juga berkompetisi dalam melakukan kebaikan dan ketakwaan. Dengan demikian, kehidupan personal maupu golongan akan lebih dinamis, kemudian melahirkan kompetisi yang sehat untuk memperoleh kebaikan (musabaqah fi al-khairat) dan saling tolong-menolong (ta'awun) dalam melaksanakan tugas pengabdian kepada Allah dan penghormatan kepada sesama makhluk.

Sebagaimana yang disampaikan Biyanto (2015, hal. 172-173) bahwa agar tidak terjadi gejala saling menyalahkan dan bahkan mengafirkan antar sesama umat Islam, maka yang harus dilakukan adalah membangun ukhuwwah Islamiyah dalam konteks kehidupan yang majemuk. Realisasi ukhuwwah Islamiyah ini pernah mewujud dalam proyek al-mu'akhah, yakni tatkala Rasulullah mempersaudarakan kaum Muhajirin dan Anshar di Madinah. Istilah ukhuwwah terasa lebih mendalam maknanya dibanding kerjasama-kerjasama yang dipelopori Nabi dengan komunitas non-muslim di Madinah. Sebab, proyek persaudaraan dalam konteks ini didasarkan pada kesamaan iman. golongan Muhajirin dan Ansar adalah kaum yang sama-sama beriman kepada Allah, karenanya perlu dipersaudarakan. Sikap Rasulullah terhadap kedua kaum tersebut merupakan implementasi ajaran etik sebagaimana dalam QS. Al-Hujurat 10:

"Sesungguhnya orang-orang mukmin adalah bersaudara karena itu damaikanlah antara dua saudaramu dan bertaqwalah pada Allah upaya kamu mendapat rahmat." 
Membangun ukhuwah, bukan berarti memaksa untuk menyatukan berbagai paham dalam Islam yang pada dasarnya berbeda, terutama pada persoalan furu'. Raealitas perbedaan justru menjadi ujian bagi umat. Hal ini berarti kelompok-kelompok dalam Islam diuji untuk menjadi golongan yang banyak memberikan kntribusi bagi kemanusiaan. Oleh karena itu, spirit fastabiqul khairat untuk menjadi yang terbaik seharusnya menjadi landasan setiap golongan dan tidak menghalangi terwujudnya ukhuwah (Azra et al., 2015, hal. 4). Toleransi dan persatuan umat Islam dapat diwujudkan tanpa harus ketakutan menghilangkan mazhab sama sekali, tujuan yang ingin dicapai juga bukan hanya untuk menyatakan bahwa satu madzhab yang benar dan menganggap selainnya salah, atau ajakan untuk tidak bermadzhab sama sekali. Bukan itu semua yang diharapkan, apalagi diupayakan, namun ajakan yang dikumandangkan adalah persatuan umat dalam arti membiarkan madzhab-madzhah Islam yang ada tumbuh berkembang, sambil melakukan pendekatan agar kesemuanya dapat bergandengan tangan, berjalan seiring dan bekerjasama meraih kejayaan bersama serta saling menopang menghadapi musuh Islam secara bersama (M. Q. Shihab, 2007, hal. 259).

Termasuk konflik Sunni-Syi'ah yang terjadi bukan hanya di Timur Tengah, tapi juga merambah ke Indonesia. Konflik Sunni-Syi'ah merupakan konflik berkepanjangan sejak zaman klasik hingga berdampak terhadap perpecahan umat Islam di berbagai belahan dunia termasuk di Indonesia yang sebenarnya dapat dipertemukan dan diselesaikan. Berbagai usaha telah dilakukan oleh kedua belah pihak termasuk para ulama untuk mengadakan dialog dan membicarakan perdamaian juga persaudaraan, serta menutup rapat-rapat sejarah kelam pertikaian keduanya Menurut Abidin (2006, hal. 125) bila perlu, Syi'ah-Sunni harus saling membuka diri terhadap kekurangan dan kelemahan masing-masing, saling menghargai, bahkan berkenan menerima kelebihan masing-masing. Dilihat dari perspektif pemikiran Islam, Syi'ah-Sunni bukanlah agama atau sesuatu yang mutlak harus dipatuhi atau diikuti. Keduanya merupakan kelompok yang berusaha memahami Islam, dan menganalisa ajaran-ajaran Islam dengan pendekatan dan metode masing-masing, maka hasilnya bersifat relatif dan tidak mutlak. Karena itu, perbedaan keduanya adalah perbedaan dalam persoalan ijtihad, bukan perbedaan prinsip. Bahkan tidak dapat dipungkiri dalam banyak hal, terdapat 
persamaan antara keduanya atau dengan kelompok lainnya, yaitu berasal dari cabang pohon yang sama. Oleh karena itu, antara Syi'ah-Sunni atau mazhab lainnya sebetulnya tidak ada pertentangan, yang ada hanya perbedaan dalam berinterpretasi terhadap ajaran Islam.

Sunni-Syi'ah memiliki mushaf yang sama, keduanya pun merujuk pada hadishadis Nabi. Perbedaan antara Sunni-Syi'ah hanyalah pada jalur pengambilan hadis, di mana Syi'ah hanya menerima hadis yang bersumber dari keluarga Nabi. Pandangan Syi'ah ini wajar sekali karena terpengaruh oleh pertikaian politik masa lalu. Pertikaian ini telah menyebabkan fanatisme dan eksklusivisme sehingga pakar hadis Syi'ah mensyaratkan pengambilan hadis hanya dari keluarga Nabi. Akan tetapi belakangan, Syi'ah sudah mulai terbuka dan mau mengkaji kitab-kitab hadis Sunni di lembagalembaga pendidikan Iran yang disebut Hauzah. Keterbukaan ini selaras dengan semangat inklusif as-Syafi'i yang juga mau menerima hadis dari ulama Syi'ah seperti Ibrahim bin Yahya, bahkan Abu Hanifah tidak segan-segan mengambil hadis dari $A h l$ al-Bait (keluarga Nabi). Sikap inklusif juga ditunjukkan oleh Syi'ah Zaydiyyah yang mau menerima hadis-hadis dari kitab-kitab hadis aliran Sunni (Masduqi, 2011, hal. 213214). Jika yang dipersoalkan adalah sejarah masa lalu, khususnya yang berkaitan dengan kepemimpinan Ali, Syi'ah sudah seharusnya tidak mempermasalahkannya lagi karena itu sudah merupakan sejarah masa lalu. Persoalan Sunni-Syiah dalam kepemimpinan atau imamah adalah bagian dari dinamika umat Islam, karena pada masa sekarang umat Islam telah hidup di negerinya masing-masing dengan sistem yang sudah ada.

Sunni ataupun Syiah tidak perlu lagi memperdebatkan dan mempermasalahkan peristiwa politik di antara para Khalifah ar-Rasyidin. Perbedaan dalam masalah kepemimpinan lebih banyak bersifat politis dan historis ketimbang teologis dan persoalan itu telah usai seiring berjalannya waktu. Bila Ali bin Abi Thalib dianggap lebih berhak menjadi pemimpin, sekarang beliau telah wafat, kita tidak dapat menghidupkannya lagi dan menyerahkan tampuk kepemimpinan kepadanya. Persoalan imamah juga bukan harga mati bagi semua golongan Syi’ah, misalnya Syi'ah Zaidiyah tidak mensyaratkan imamah harus dari keturunan Ali. Begitu juga dengan golongan Sunni pada saat itu bukanlah pengikut Abu Bakar, Umar, Usman, maupun Muawiyah. Perpecahan Sunni dan Syi'ah merupakan persoalan politik masa lalu, sudah seharunya 
umat Islam tidak tidak hanya berkutat pada masa lampau. Merugilah kita bila emosi dan pikiran kita hanya mempersoalkan politik masa lalu. Tidak perlu lagi meratapinya dan seharusnya sudah melupakan pertikaian tersebut demi mewujudkan kedamaian di masa depan (Masduqi, 2011, hal. 208-209).

Sebagai umat yang satu dengan beragam pemahaman terhadap al-Quran dan Sunnah tidak lantas membuat umat Islam saling menjatuhkan. Sebagai saudara sudah seharunya saling menjaga dan menghormati. Tidak layak bagi sesama saudara saling membenci, bermusuhan, mencaci apalagi berkata kasar. Semua pemahaman dan pengamalan ajaran agama Islam selama tidak radikal dan ekstrem dapat diterima. Lisan dan perasangka terhadap kelompok yang berbeda dengan kita hendaknya tetap dijaga, tidak lantas menjustifikasi mereka sebagai kelompok yang salah, sesat, bid'ah dan kafir. Karena bila menggunakan logika terbalik, saat kita beranggapan bahwa kelompok tertentu misalnya sesat, maka bisa jadi kebalikannya justru kelompok tersebut beranggapan bahwa kelompok kita yang sesat. Bermazhab itu boleh, tapi yang tidak boleh adalah bertaklid buta tanpa memahami dengan jelas dan menyalahkan orang lain, karena masing-masing kelompok pasti memiliki dalil dan argumen tersendiri atas apa yang sudah diyakini dan dikerjakan.

Kehidupan yang damai dengan adanya nilai-nilai persatuan dan persaudaraan dalam bentuk toleransi antar umat Islam akan terwujud bila semua kelompok dan elemen terkait saling mengerti dan mendukung. Menurut Suryana (2011, hal. 130) persatuan umat Islam memang tidak dapat terwujud seiring masih adanya perbedaan kepentingan dari masing-masing kelompok. Perpecahan sering kali timbul karena suatu hal yang tidak mendasar. Permasalahan agama, sering kali terjadi perbedaan pendapat dan penafsiran atas suatu hukum yang kemudian hari melahirkan banyak pandangan dan mazhab. Perbedaan pendapat dan penafsiran merupakan fenomena biasa dan manusiawi. Dalam menyikapi kondisi tersebut agar mewujudkan persatuan dan menghindarkan perpecahan para ahli mengetengahkan tiga konsep yang harus dipahami bersama. Pertama, konsep tanawwul al-ibadah yaitu keragaman cara beribah yang dipraktekan oleh Nabi. Kedua, konsep al-mukhtiu fi al-ijtihadi lahu ajrun (kesalahan dalam berijtihad tetap mendapat ganjaran). Ketiga, konsep la hukma lillah qabla ijtihadi al-mujtahid yaitu Allah belum menetapkan suatu hukum sebelum seorang 
mujtahid melakukan ijtihad. Ketiga konsep tersebut memberikan pemahaman bahwa ajaran Islam mentolerir adanya perbedaan pemahaman maupun pengamalan dalam umat Islam, karena semua itu adalah hasil interpretasi manusia. Perbedaan tidak harus dipertentangkan dan menimbulkan permusuhan. Konsep tentang ishlah memiliki peranan dalam menyelesaikan pertentangan yang ada, sehingga dapat menyatukan kelompok yang saling bertikai.

Begitu juga dengan berdakwah, sesama umat Islam diharapkan tidak menyinggung atau membahas hal-hal atau amalan yang diyakini dan diamalkan oleh kelompok lain dan dapat menimbulkan konflik internal, seperti persoalan tahlilan-tidak tahlilan, maulidan, shalawatan, ziarah kubur, qunut shalat subuh atau tidak dan masih banyak yang lainnya. Seandainya tetap diperlukan untuk disampaikan, maka lebih baik menjadi konsumsi pribadi atau sesame kelompoknya saja tanpa menyebarkan kepada masyarakat secara umum dan menyalahkan golongan lain. Arib (2014, hal. 40) menegaskan tiga persoalan mendasar yang harus senantiasa diupayakan, jika Islam diharapkan menjadi rahmah untuk seluruh alam yaitu pertama, penyiapan da'i yang arif sekaligus bersikap inklusif, bukan ekslusif; Kedua, memilih materi dakwah yang menyejukkan dan, ketiga, dakwah berparadigma transformatif sebagai modal menuju kerjasama antar umat beragama. Yang pertama, erat kaitannya dengan penyiapan kompetensi personal seorang dai sedang sisanya kompetensi penunjang yang harus menjadi concern seorang pendakwah atau muballig.

Akan indah bila semua masjid akan dapat dinikmati sebagai tempat ibadah seluruh umat Islam tanpa harus tersekat masing-masing golongan. Umat Islam pun tidak harus mempersoalkan lagi qunut atau tidak, termasuk jumlah rakaat tarawih dan di bulan Ramadan. Umat Islam dapat shalat bersama berjamaah dengan tenang meski berbeda mazhab. Dalam hal Imam, masjid dapat menggilir imam sesuai dengan organisasi Islam atau mazhab yang dianut. Toleransi dalam beribadah sesuai dengan mazhabnya telah dipraktekan oleh para pendahulu kita yaitu mengedepankan akhlak di atas fiqih (Rusmana \& Rahtikawati, 2014, hal. 303). Sebagaimana yang pernah dicontohkan Imam Syafi'i tentang toleransi sesama umat Islam yang berbeda mazhab, antara imam Mazhab Fiqh Imam Abu Hanifah dan Imam Syafi'i. Suatu ketika Imam Syafi'i shalat di Bagdad dan tidak melakukan qunut saat shalat subuh. Ketika ditanya 
kenapa ia melakukan hal tersebut, Imam Syafi'i mengatakan bahwa ia melakukannya karena menghormati Abu Hanifah yang dikuburkan di Bagdad.

\section{Simpulan}

Wafatnya Nabi menjadi pintu gerbang perpecahan umat Islam. Ada dua hal penting yang menjadi perdebatan panjang sepanjang sejarah yang melahirkan berbagai aliran teologi Islam, yaitu persoalan kepemimpinan dan otoritas pasca Nabi. Perbedaan pemahaman dan interpretasi atas al-Quran dan Sunnah terjadi di antara aliran dan mazhab dalam Islam. Keberadaan aliran teologi dan mazhab sering kali diwarnai dengan perseteruan di antara para pengikutnya, bahkan konflik ini berlangsung terus menerus. Karena perbedaan, orang mudah menjustifikasi orang lain dengan label sesat, bid'ah dan kafir. Bahkan tidak sedikit yang berani menghalalkan darah sesama umat Islam hanya karena perbedaan tersebut. Persatuan umat Islam akan terwujud jika sesama umat Islam tidak mengedepankan ego masing-masing individu dan kelompok. Saling memahami bahwa perbedaan adalah sebuah hal yang wajar tanpa harus dibesarbesarkan. Jika memang dalam sejarahnya umat Islam pernah saling berseteru, maka biarkanlah sejarah itu berlalu tanpa harus selalu mempersoalkan sejarah tersebut. Resolusi konflik masa lalu perlu terus dilakukan untuk sama-sama mencari titik temu dan persatuan.

Paradigma dan wacana internal umat Islam tidak lagi mempermasalahkan perbedaan antar golongan tapi lebih banyak mendiskusikan ayat-ayat dan hadis persatuan dari pada mempersoalkan perbedaan yang ada. Toleransi antar umat Islam dalam kehidupan dan beribadah sangatlah penting. Biarkan semua umat Islam beribadah sesuai dengan ajaran Islam dan pemahaman mazhab yang dianut. Semua pihak perlu bekerja sama dengan baik dan tidak memicu konflik. Dalam berkomunikasi dan berinteraksi pun hendaknya tidak menyinggung dan mempermasalahkan perbedaan yang ada. Dakwah dengan berbagai komponennya termasuk metode dan kader dakwah perlu menghindari pernyataan provokatif yang dapat menimbulkan perseteruan antar umat. Selain itu, metode dan cara dakwah yang digunakan bersifat lunak dan lemah lembut dan tidak mudah menyesatkan, membid'ahkan dan mengkafirkan orang lain. Dengan begitu akan tercipta kehidupan yang damai dan toleran. Meskipun berbeda-beda, umat Islam tetaplah satu dan bersaudara. 


\section{Referensi}

Abdillah, N. (2014). Madzhab dan Faktor Penyebab Terjadinya Perbedaan. Fikrah: Jurnal Studi Ilmu Aqidah dan Studi Keagamaan, 2(1).

Abidin, Z. (2006). Syi'ah dan Sunni dalam Perspektif Pemikiran Islam. Hunafa: Jurnal Studi Islamika, 3(2).

Ahmad, A. (2015). Tadabbur al-Hadìts: Solusi Masalah Khilafiyah. Ilmu Ushuluddin. Ilmu Ushuluddin, 23.

Aisyah BM, S. (2014). Konflik Sosial dalam Hubungan Antar Umat Beragama. Jurnal Dakwah Tabligh, 15(2).

Al-Qadri, A.-H. J. (2012). Bijak Menyikapi Perbedaan Pendapat: Telaah atas Pemikiran Al-Habib Umar bin Haffizh dalam Membina Ukhuwah dan Membangun Dialog. Bandung: Mizan Pustaka.

Alfandi, M. (2013). Prasangka: Potensi Pemicu Konflik Internal Umat Islam. Walisongo: Jurnal Penelitian Sosial Keagamaan, 21(1).

Andiko, T. (2013). Andiko, Toha. (2013). Melacak Akar Konflik dalam Islam dan Solusi Bagi Kerukunan Umat Beragama di Indonesia. . 17(1). MADANIA: Jurnal Kajian Keislaman, 17(1).

Arib, M. (2014). Dakwah di Tengah Keragaman dan Perbedaan Umat Islam. Jurnal Dakwah Tabligh, 15(1).

Azra, A. (1999). Konteks Berteologi di Indonesia. Jakarta: Paramadina.

Azra, A., Biyanto, Ilyas, H., Riyadi, H., Latief, H., Saifuddin, L. H., ... Qodir, Z. (2015). Berdamai dengan Perbedaan. In W. G. A. Wahid, M. A. Darraz, \& A. F. Fanani (Ed.), Fikih Kebinekaan. Bandung: Mizan.

Bagir, H. (2017). Islam Tuhan Islam Manusia: Agama dan Spiritualitas di Zaman Kacau. Bandung: Mizan.

Biyanto. (2015). Berdamai dengan Pluralitas Paham Keberagaman. Teosofi: Jurnal Tasawuf dan Pemikiran Islam, 5(1).

Farihah, I. (2014). Strategi Dakwah di Tengah Konflik Masyarakat. Addin, 8(2).

Harahap, S. (2011). Teologi Kerukunan. Jakarta: Prenada.

Hatta, M. (2013). Aliran Mu'tazilah dalam Lintasan Sejarah Pemikiran Islam. Ilmu Ushuluddin, 1. 
Jamrah, S. A. (2015). Studi Ilmu Kalam. Jakarta: Kencana.

Kahmad, D. (2002). Sosiologi Agama. Bandung: Remaja Rosda Karya.

Latiff, A. Z. H. A. (2003). Isu Kafir-Mengkafir dan Implikasinya dalam Perkembangan Politik dan Sosial Masyarakat Melayu. Jurnal Ushuluddin, Bil 17.

Madjid, N. (1993). Satu Islam: Sebuah Dilema. In S. Bashri (Ed.), Menegakkan Faham Ahlu Sunnah Wal Jama'ah Baru. Bandung: Mizan.

Masduqi, I. (2011). Berislam Secara Toleran: Teologi Kerukunan Umat Beragama. Bandung: Mizan.

Mulyono, S. (2012). Pergolakan Teologi Syi'ah-Sunni: Membedah Potensi Integrasi dan Disintegrasi. Ulumuna: Jurnal Studi Keislaman, 16(2).

Nasution, H. (1986). Teologi Islam: Aliran, Sejarah, Analisa dan Perbandingan. Jakarta: IU Press.

Nurdin, M. A., \& Abbas, A. F. (2012). Sejarah Pemikiran Islam. Jakarta: Amzah.

Purnama, F. F. (2016). Khawarijisme: Pergulatan Politik Sektarian Dalam Bingkai Wacana Agama. Al-A'raf: Jurnal Pemikiran Islam dan Filsafat, 13(2).

Rakhmat, J. (2004). Islam Aktual: Refleksi Sosial Seorang Cendikiawan Muslim. Bandung: Mizan.

Rumadi. (2012). Islam dan Otoritas Keagamaan. Walisongo: Jurnal Penelitian Sosial Keagamaan, 20(1).

Rusli, R. (2015). Teologi Islam: Telaah Sejarah dan Pemikiran Tokoh-Tokohnya. Jakarta: Kencana.

Rusmana, D., \& Rahtikawati, Y. (2014). Tafsir Ayat-ayat Sosial Budaya: Tafsir Maudhu'i Terhadap Ayat-ayat Al-Qur'an yang Berkaitan dengan Budaya, Sejarah, Bahasa dan Sastra. Bandung: Pustaka Setia.

Shihab, M. Q. (2007). Sunnah-Syi'ah Bergandengan Tangan! Mungkingkah?: Kajian atas Konsep Ajaran dan Pemikiran. Jakarta: Lentera Hati.

Shihab, U. (2017). Beda Mazhab, Satu Islam. Jakarta: Elex Media Komputindo.

Siroj, S. A. (2012). Tasawuf Sebagai Kritik Sosial: Mengedepankan Islam Sebagai Inspirasi, Bukan Aspirasi. Jakarta: SAS Foundation dan LTN PBNU.

Suryana, T. (2011). Konsep dan Aktualisasi Kerukunan Antar Umat Beragama. Ta'lim: Jurnal Pendidikan Agama Islam, 9(2). 
Syak’ah, M. M. (2008). Islam Tanpa Mazhab. Surakarta: Tiga Serangkai.

Tuakia, H. (2015). Integrasi Sosial Kelompok Faham Keagamaan dalam Masyarakat Islam. Salam, 18(1).

Waskito, A. M. (2012). Mendamaikan Ahlus Sunnah di Nusantara: Mencari Titik Kesepakatan Antara Asy'ariyah dan Wahabiyah. Jakarta: Pustaka Al-Kautsar.

Yunus, F. M. (2014). Konflik Agama di Indonesia Problem dan Solusi Pemecahannya. Substantia: Jurnal Ilmu-ilmu Ushuluddin, 16(2). 